\title{
Some palaeoecological data from Rondonia, southern part of the Amazon Basin. $\left(^{*}\right)$
}

Maria Lúcia Absy (')

Th. van der Hammen $\left({ }^{2}\right)$

\begin{abstract}
Palynological investigations on sediment cores from three localities in Rondonia in the southern part of the Amazon Basin, indicate that marked vegetational changes have ocurred there. The series of samples from Katira represents the late Cenozoic, probably Quaternary. The sediments from Capoeira might be partly of Holocene age (and possibly Upper Pleistocene as well). Apparently the climatic changes during several intervals of the Late Cenozoic (Quaternary) caused the development of savannas in this region which is now covered in tropical forest.
\end{abstract}

\section{INTRODUCTION}

It is now generally accepted that during dry periods in the Pleistocene the Amazon forest was reduced to a number of isolated patches or refuges and the rest of the area was covered with open vegetation. This theory of the existence of forest refuges was postulated by Haffer (1969) from his studies on the speciation of Amazonian birds .

Subsequently Vanzolini and Williams (1970) and Vanzolini (1973) have presented substantial evidence from lizard studies to support this theory, as have Brown and Mielke (1972), Brown (1975), Brown et al. (1974), for Heliconiid butterflies and Prance (1973) for several plant families.

However, most of the support for the theory in the papers mentioned above has been collected from studies on the distributions of extant species and the use of the data to interpret climatic changes in the Pleistocene is necessarily an extrapolation.
Palynological evidence from cores of sediment samples from Rondonia have shown that grass-savanna replaced the tropical forest during a particular interval of the Pleistocene age (Hammen, 1972 and 1974).

It seems that the vegetational changes resulting from the fluctuations in climate caused movements of the populations of indigenous people as has been suggested by Meggers and Evans (1973).

Recently Journaux (1975) has given geomorphological data indicating climatic changes during the Quaternary in the Amazon Basin.

The pollen diagrams presented here are based partially on the same material mentioned by Hammen $(1972,1974)$.

At the present time the Amazon Basin is largely covered by forest but some areas have a savanna vegetation which may serve as refuges for species of plants and animals that do not live in the forest. The localities from which samples were collected are at present forested and the nearest area covered with open vegetation type is found at a distance of about $300 \mathrm{Km}$.

\section{THE PRESENT VEGETATION}

The important information on the present vegetation of Rondonia has been given by $\mathrm{Dr}$. Ghillean T. Prance (personal communication).

The present day vegetation of Rondonia is predominantly tropical rain forest except for a few areas of other vegetation types. The forest of the Rio Machado region is one of the

\footnotetext{
( $\%$ - This research was initiated at Hugo de Vries Labo ratory of Amsterdam with a grant of the Dutch government and carried out in the Instituto Nacional de Pesquisas da Amazônia.

(1) - Instituto Nacional de Pesquisas da Amazônia, Manaus.

(2) - Hugo de Vries Laboratorium, Afdeling Palynologie, University of Amsterdam, Netherlands.
} 
tallest and richest in species of the entire Amazon basin. In the South of Rondonia and east of the Chapada dos Parecis there is a line of isolated patches of savanna that are closely related phytogeographically to the Cerrados of Central Brasil. The hilly part of Rondonia, specially the Serra do Pacaás Novos and the Chapada dos Parecis has a lower upland scrub vegetation near to the summits. This area is little known botanically and has much local endemism of plant species. Near to the Rio Madeira at Abunã there is a large palm swamp with a large number of palms and a grassy ground cover.

The three areas studied are all well with in the species rich rain forest area between the Rios Jamari and Machado. They are distant from any open vegetation, but it is interesting that Savanna vegetation occurs at about 300 $\mathrm{Km}$ distance both to the North and to the South. To the North are the large savannas of Humaitá which have isolated patches north of the Rio Madeira almost to Porto Velho. To the South are the isolated patches of savanna related to the Cerrados. Perhaps both these Savanna areas North and South of the region studied are relics of the much more widespread Savannas of the dry periods.

\section{METHODS}

\section{SAMPLES COLLECTED}

The material was collected in Rondonia (Fig. 1) in three localities: Katira, Capoeira and Rio Preto (Fig. 2).

All samples were boiled for 10 minutes in a 10 percent $\mathrm{KOH}$ aqueous solution (Faegri \& Iversen, 1966), followed by acetolysis (Erdtman, 1960) and a specific-gravity separation by use of a bromoform-alcohol mixture (Kummel \& Raup. 1965).

The pollen grains were mounted in glycerin jelly for examination at magnification up to $\mathrm{X} 1000$.

\section{IDENTIFICATION OF THE POLLEN GRAINS}

Most of the pollen grains were identified with the aid of published descriptions and keys and comparisons with the collection of recent pollen in the Hugo de Vries Laboratory, Amsterdam.

Identification of most types was possible to the family and in some cases to the generic level.

The pollen grains not so classified were named provisionally according to the type of apertures.

Of the types of pollen mentioned in this study most have been illustrated by Absy (1975) and some are illustrated here. (Plate I, 1-7).

\section{POLLEN DIAGRAM}

The method used for the composition and illustration of the diagrams, showing the fluctuations of the pollen belonging to several groups of plants was based on Wymstra \& Hammen (1966).

In the diagrams the sum of herb and arboreal pollen was used as a basis for calculation of the percentage occurrence of pollen.

For each sample a minimum of 200 pollen grains were counted. In only one case it was not possible to obtain this total amount because of insufficient pollen.

The spores were excluded from the sum of the total pollen, but their numbers were expressed as percentages of that sum.

The spectra of the general diagram represent a cumulative percentage of polien and thus it is related to $100 \%$ of the total counted pollen grains.

In this diagram the pollen percentages of the following plants were represented from left to right.

\section{Results}

1 - Gramineae.

2 - Compositae, Cuphea.

3 - Labiatae, Leguminosae, Ranunculus and Cyperaceae.

4 - Byrsonima, Curatella.

5 - Mauritia. 


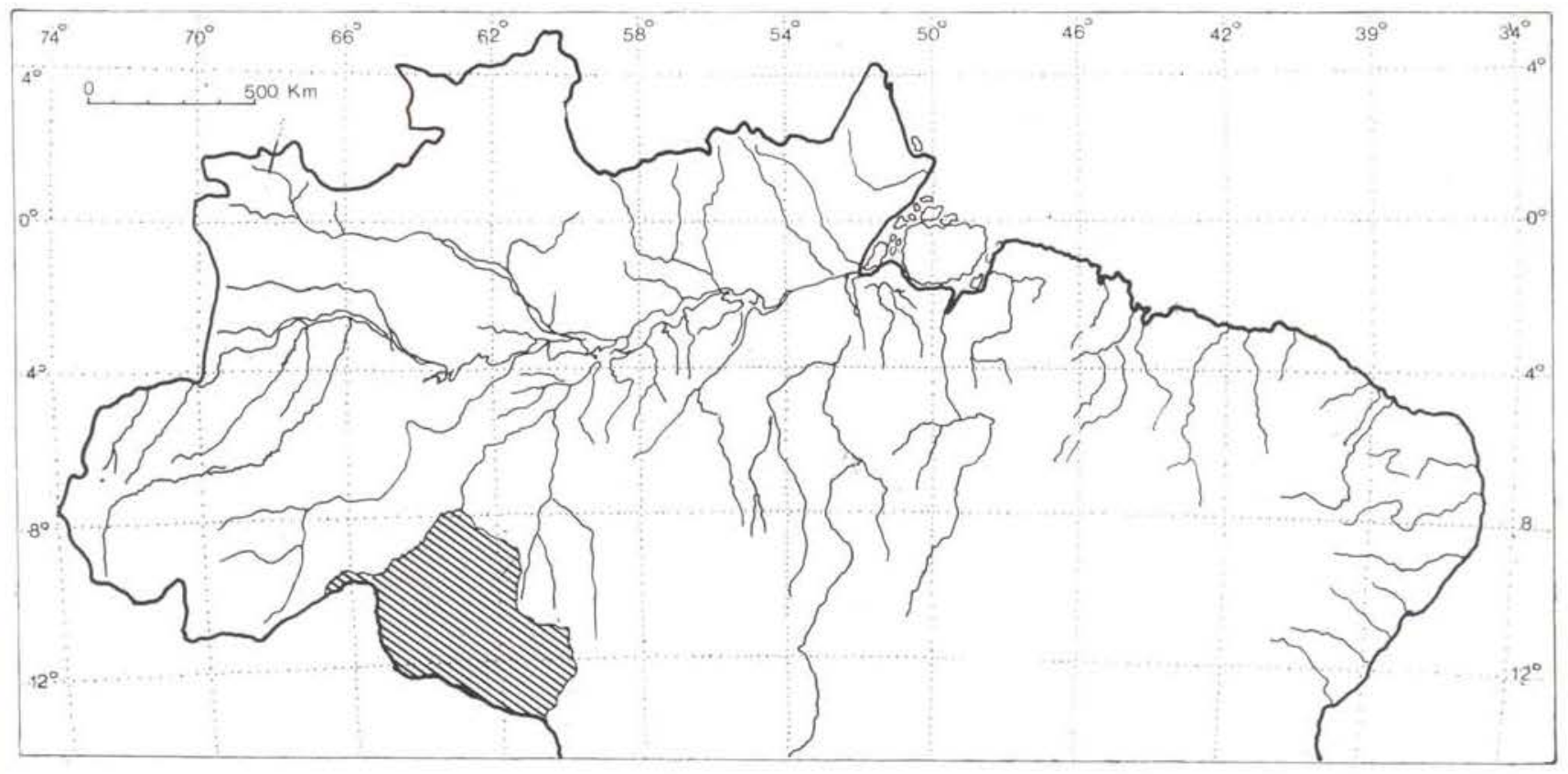

Fig. 1-Map of northern Brasil showing Rondonia.

On the right of the general diagram we find the individual curves of all pollen and spore types studied.

To facilitate the discussion, the diagram has been divided into pollen zones according to marked changes. These pollen zones are represented by letters, followed by the number of the diagram.

The lithological column of the section sampled is illustrated on the left of the diagram.

For the location of the pollen core sites, see Fig. 2.

Diagram I (Fig. 3)

\section{Katira}

According to marked vegetation changes shown in the diagram it was divided into three pollen zones: A- I; B-I and C-I.

There is a high percentage of Gramineae in a greater part of the diagram.

The percentages of the pollen of the trees, mainly Mauritia, show a dominance compared with the pollen of herbaceous elements. A relatively high percentage of Palmae, Myrtaceae, Alchornea, Miconia and Ilex also characterize this zone.

There is an increase in the curves of Gramineae and Cyperaceae and a general decrease in the curves of the spores.

The B- I zone is characterized by a high percentage of Gramineae and Cyperaceae which reaches a maximum in the limit of the transition between the zones A- I and B- I.

High numbers of Compositae, Cuphea and Labiatae pollen are also represented in the B- I zone.

The percentages of the pollen of the trees and of spores decrease considerably.

This zone is formed of black clay at the top and grey clay in the basal part.

The $\mathrm{C}$ - I zone shows a complete dominance of the herbaceous elements with a high percentage of Gramineae.

The curves of Compositae and Cuphea decline towards the top of the zone and the curve of Cyperaceae remains constant. 


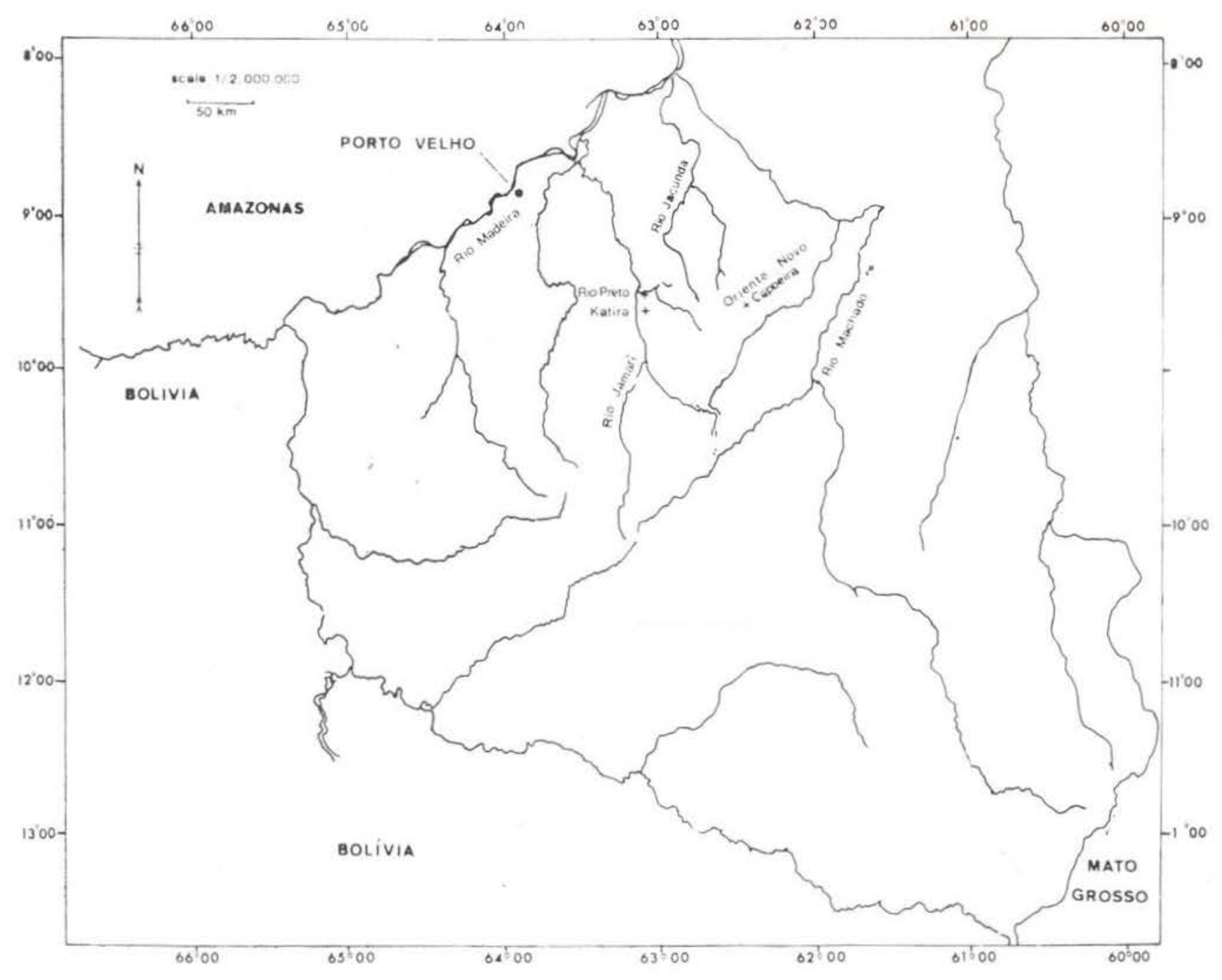

Fig. 2 - Map of Rondonia indicating the localities of the pollen sections.

There is an increase in the percentages of pollen of Mauritia, Palmae, Myrtaceas and Malpighiaceae.

The curve of psilate monolete spores rises again in this zone.

Lithologically light clay and black clay form this zone.

Diagram II (Fig. 4)

\section{Capoeira}

The pollen zones represented in this diagram are : $\mathrm{A}$ - II, B-II and C-II.

The percentage of the pollen of the trees is well represented in the A- II zone.
Palmae, Iriartea, Didymopanax and Guttiferae pollen curves remained constant.

At the transition point between $A-I I$ and B- II zones the percentage of Symphonia rises to a relatively high proportion and the curves of most of the tree pollen fall. The percentage of Gramineae is considerably higher.

The curves of the psilate monolete and trilete spores show an increase.

The A- II zone is formed of sandy and humic material.

A dominance of pollen of open vegetation, represented by high values of Gramineae, characterize the B- II zone. 
There is an increase in the curves of: Palmae, Iriartea, Didymopanax, Alchornea, Anacardiaceae and Protium.

In the B- II zone the curves of Artemisia and Leguminosae rise and the percentage of Gramineae decreases towards the top of this zone.

The curves for psilate monolete and trilete spores are relatively high.

Lithologically this zone is formed of sandy and humic material.

In the C- II zone the proportions of most of the pollen of the trees rises until the end of the zone.

The curves of Mauritia and Palmae increase while the curve of Iriartea decreases.

The percentages of Alchornea, Anacardiaceae, Cecropia, Ficus, Urticaceae, Ulmaceae and Virola, are relatively high in this zone and the curve of Gramineae decreases sharply.

The monolete and trilete spores show high percentages.

Lithologically sandy and humic material forms this zone.

Diagram III (Fig. 5)

\section{Rio Preto}

This zone is formed of a humus with some clay and of a rock basement.

The percentages of Myrtaceae, Didymopanax, Byrsonima, Curatella, Anacardiaceae, Rubiaceae and Urticaceae are high, diminishing towards the top. The curve of Alchornea remains constant.

The Gramineae are well represented.

Of the spores, the curve of the psilate monolate and trilete spores show an increase.

\section{DISCUSSION AND CONCLUSIONS}

From the data supplied by the pollen diagrams it is probable that at least this part of Rohndonia supported a grass savanna during at least some intervals of the Late Cenozoic (Quaternary.) This vegetational type is ty- pical of tropical regions that receive a more limited rainfall and marked alternation of dry and wet seasons.

The dominance of open vegetation with mainly grasses, e. g. Cuphea and Cyperaceae in Katira, and their abundance in Capoeira and Rio Preto suggests that savanna existed in this area.

The diagrams examined show marked changes in the vegetation from forest or woodland to open savanna. A rich flora, characterized the tropical forest with Mauritia, Iriartea and other palms, Ilex, Symphonia, Miconia, Alchornea, Didymopanax, Myrtaceae, Melastomataceae, etc.

The presence of Symphonia, Hedyosmum, and Compositae Liguliflorae in the Katira section would indicate a Pliocene to Late Quaternary age. The sediments of Capoeira might be a Late Quaternary. The pollen content of the uppermost sediments of this section is in agreement with the present vegetation.

Although the results of the present study, provide no detailed evidence of climatic changes, the latter probably caused the development of savanna in the area under discussion.

Other evidence on fluctuations of savanna forest boundaries was given by Wymstra \& Hammen (1966) with regard to pollen diagrams from the Llanos Orientales (Colombia) and the Rupununi Savanna (Guiana). Open savanna existed in the first mentioned region particularly about 4.000 BP and in the other region in the later part of the "Last Glacial".

The data presented here support the zoological, archeological and botanical evidences for the theory of forest refuges. Howewer, further investigation and $\mathrm{C} 14$ analy. sis of the sediments may yield more information to substantiate this theory.

\section{ACKNOWLEDGMETNS}

The authors thank the Billiton Company who kindly provided the sediment samples and the Dutch Government for partially supporting the work with a grant. 


\section{RESUMO}

O conceito de que houve períodos de clima seco durante o Pleistoceno na Amazonia, vem sendo debatido por inúmeros pesquisadores nos últimos anos. A teoria dos refúgios, proposta por Haffer, deu início a uma série de estudos para a explicaçăo das mudanças climáticas da área amazônica. A maioria desses estudos foram baseados na distribuição atual de certas espécies de plantas e animais. Entretanto, o uso de dados para interpretação das flutuaçōes climáticas no Pleistoceno exige uma extrapolação. Evidências palinológicas de Rondônia mostraram que savanas de gramíneas substituiram a floresta tropical durante certos períodos do Pleistoceno.

Neste trabalho são discutidos os resultados da análise de pólen de amostras de sedimentos de Rondônia. Os diagramas polínicos mostraram mudanças na vegetação de floresta para savana $c$ vice-versa. Os sedimentos de Katira devem ser de idade Cenozóica Superior, provavelmente Quaternária. Os sedimentos de Capoeira representam em parte uma idade do Holoceno (e, possivelmente, do Pleistoceno Superior). As condições climáticas ocorridas durante certos intervalos do Cenozóico Superior (Quaternário) parecem ter favorecido ao desenvolvimento de savanas na área em discussāo, que é atualmente coberta pela floresta tropical.

\section{LITERATURE CITED}

ABSY, M.L.

1975 - Pólen e esporos do Quaternário de San. tos (Brasil). Hoehnea, $5: 1-26$.

BROWN JR., K.S.

1975 - Geographical patterns of evolution in Neotropical Lepidoptera. Systematics and derivation of known and new Heliconiini (Nymphalidae:Nymphalinae). J. Ent. (B) $44(3): 201-242$.

BROWN JR., K.S. \& MIELKE, O.F.F.

1972 - The Heliconians of Brazil (Lepidoptera: Nymphalidae) Pt. II. Introduction and general comments, with a suplementary revision of the tribe. Zoologica (N.Y. Zoological Society).

BROWN JR., K.S.; TURNer, J.R.G. \& Sheppard, P.M.

1974 - Quaternary refugia in tropical America: evidence from race formation in Helico. nius butterflies. Proc. Royal Soc. Lon. don B. $187: 369-378$.

Erdtman, G.

1960 - The" acetolysis method: - a revised description. Sv. Bot. Tidskr Lund, $54(4): 561-564$.
FAEGri, K. \& IVERSEN, J.

1966 - Textbook of pollen analysis. 2. ed. Copenhagen: Munksgaard, 228 p., 8 pl., 23 fig., 8 tab.

HAFFER, J.

1969 - Speciation in Amazonian forest birds Science, $165: 131-137$.

HAMMEN, T. VAN DER.

1972 - Changes in vegetation and climate in the Amazon basin and surrounding areas during the Pleistocene. Geologie mijnb., 51, 641-643.

1974 - The Pleistocene changes of vegetation and climate in tropical South America, Journ. Biogeogr., 1:3-26.

Journaux, A.

1975 - Recherches géomorphologiques en Amazonie brésilienne. Bull, Centr. Géomorph., Cahen, $20: 3-68$.

KUMMEL, B. \& RAUP, D.

1965 - Handbook of Paleontological techni. ques. San Francisco and London, Freeman and Company, xiii +852 p., ilustr.

MEggers, B.T. \& EVANs, C.

1973 - A reconstituição da pré-história amazô. nica. Algumas consideraçōes teóricas. In: O Museu Goeldi no Ano do Sesquicentenário. Publ. Av. Mus. Pa. Emílio Goeldi, Belém, 20 : 51-69.

PRANCE, G.T.

1973 - Phytogeographic support for the theory of Pleistocene forest refuges in the Amazon Basin, based on evidence from distribution patterns in Caryocaraceae, Chrysobalanaceae, Dichapetalaceae and Lecythidaceae. Acta Amazonica, 3(3): 5-26.

VANZOLINI, P.E.

1973 - Paleoclimates, Relief, and Species Mul. tiplication in Equatorial Forest. In: Meggers, B.J. et alii. - Tropical Fo. rests Ecosystems in Africa and South America. A comparative review. Was hington. Smithsonian Press. p. 255 1 fig.

Vanzolini, P.E. \& Whllams, E.E.

1970 - South American anoles: the geographic differentiation and evolution of the Anolis chrysolepis species group (Sauria, Iguanidae) Arg. Zool. S. Paulo, $19: 1-240$.

WYMSTRA, T.A. \& HAMMEN, T. VAN DER.

1966 - Palynological data on the history of tropical Savannas in Northern South America. Leidse Geol, Meded., $38: 71-90$, 15 fig., $7 \mathrm{pl}$. 


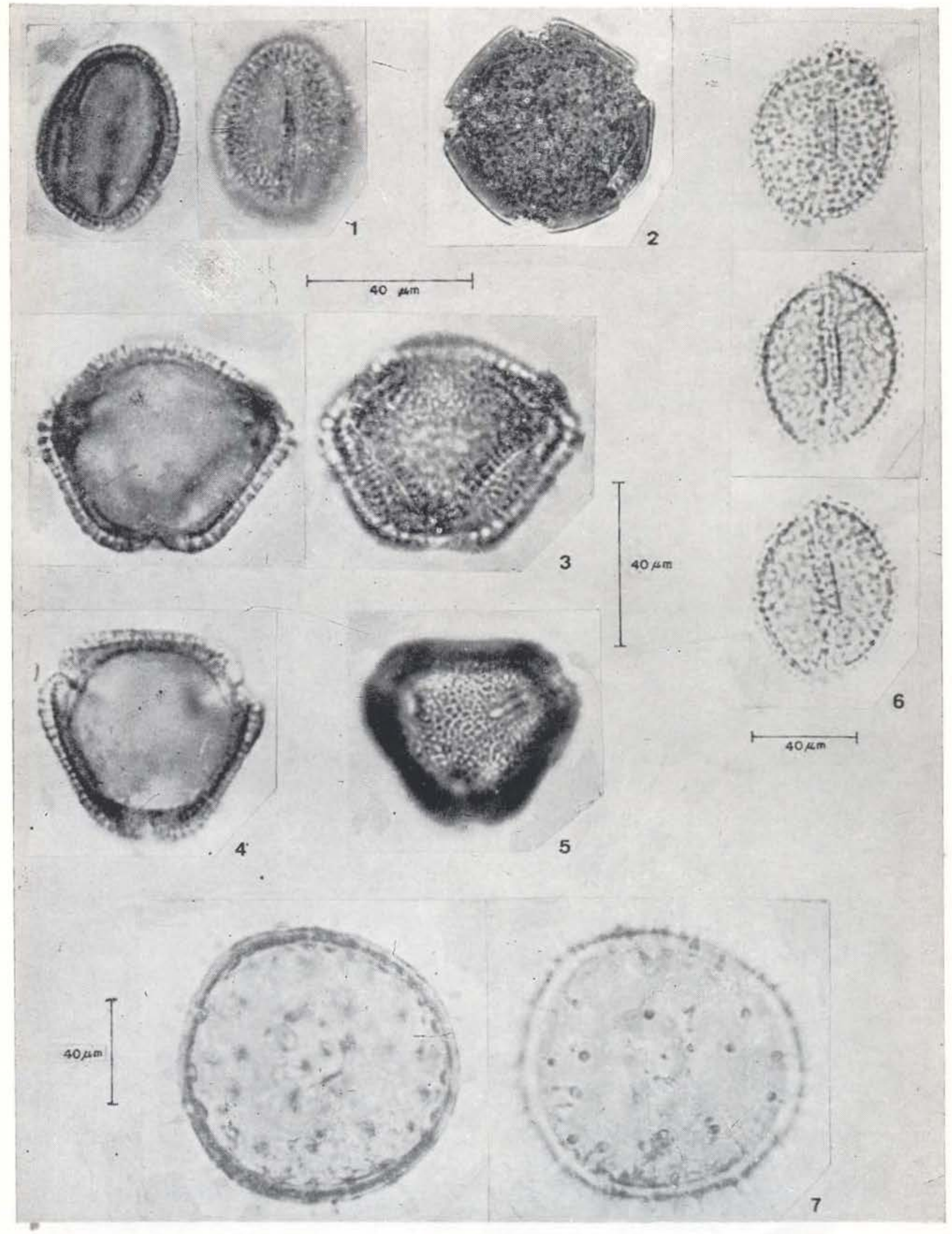

PLATE I: - Fig. 1 - Guratella (Dilleniaceae); Fig. 2 - Symphonia (Guttiferee); Fig. 3-5 - Didymopanax (Araliaceae); Fig. 6 - Iriartea (Palmae); Fig. 7 - Mauritia (Palmae). 


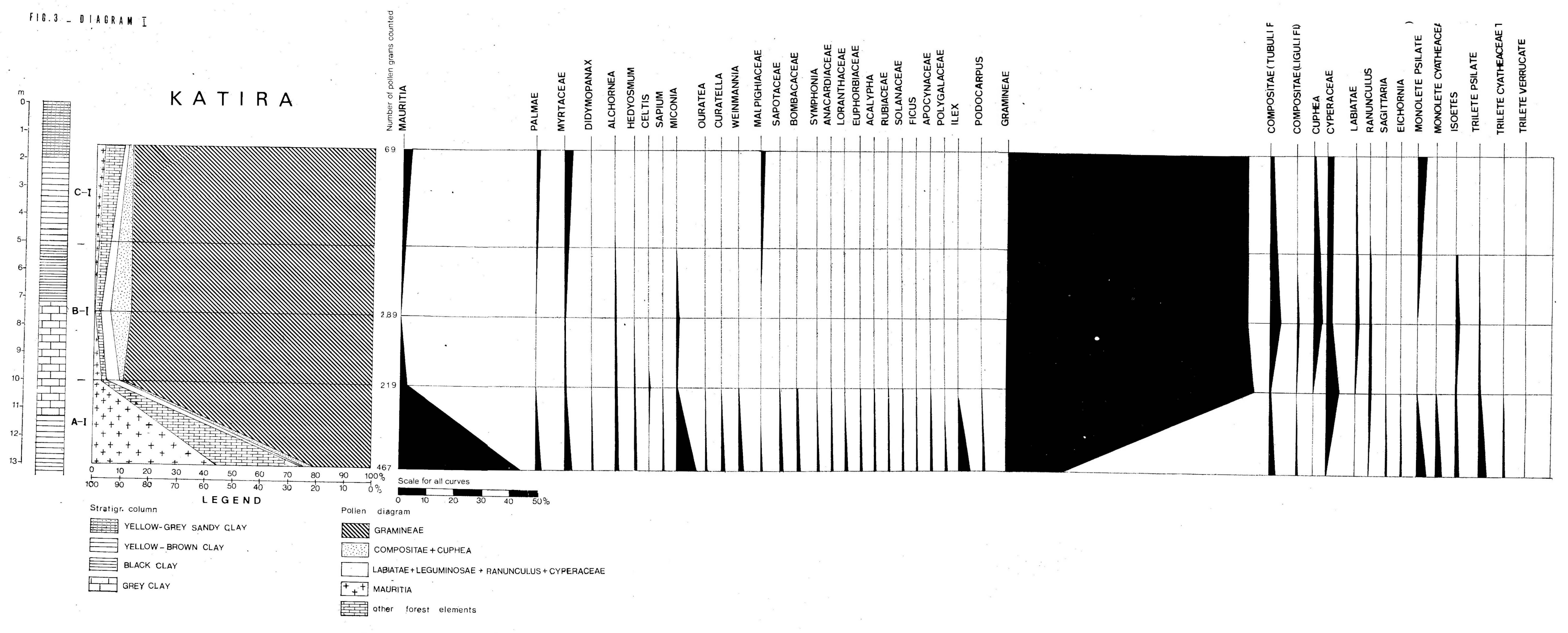


FIG. 5 - DIAGRAM III

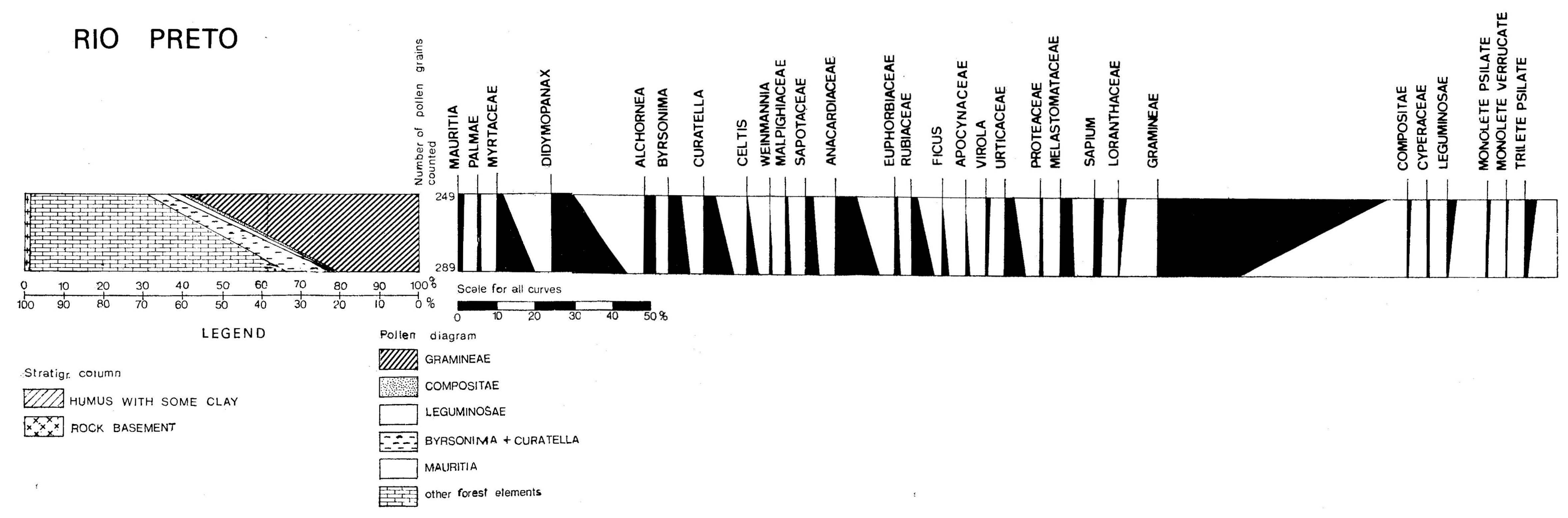

FIG. 5 - DIAGRAM III

some palaeoelogical data. Some palaeoelogical data 